This is an accepted manuscript. Cite as: Singh, M., Kaptchuk, T. J, \& Henrich, J. (in press) Small gods, rituals, and cooperation: The Mentawai water spirit Sikameinan. Evolution \& Human Behavior.

\title{
Small gods, rituals, and cooperation The Mentawai water spirit Sikameinan
}

\author{
Manvir Singh ${ }^{1 *}$, Ted J. Kaptchuk ${ }^{2}$, and Joseph Henrich ${ }^{1}$ \\ ${ }^{1}$ Department of Human Evolutionary Biology, Harvard University \\ ${ }^{2}$ Program in Placebo Studies, Beth Israel Deaconess Medical Center, Harvard Medical School
}

*Corresponding author: manvirsingh@fas.harvard.edu

\begin{abstract}
Cognitive and evolutionary research has overwhelmingly focused on the powerful deities of large-scale societies, yet little work has examined the smaller gods of animist traditions. Here, in a study of the Mentawai water spirit Sikameinan (Siberut Island, Indonesia), we address three questions: (1) Are smaller gods believed to enforce cooperation, especially compared to bigger gods in larger-scale societies? (2) Do beliefs in these deities encourage people to engage in behavior that would otherwise be perceived as costly? and (3) Does ritual reinforce beliefs in these deities? Drawing on interview responses, data from healing ceremonies, and ethnographic observation, we show that Sikameinan is believed to punish people who violate meat-sharing norms and that people 'attacked' by Sikameinan pay shamans to conduct healing rituals. The public nature of rituals, involving prestigious individuals apologizing to Sikameinan for the patient's stinginess, reinforce onlookers' beliefs about Sikameinan. The most widely shared beliefs about Sikameinan are represented in rituals while beliefs not represented vary considerably, indicating that ritual may be potent for cultural transmission. These results suggest that moralizing supernatural punishers may be more common than suspected and that the trend in the cultural evolution of religion has been an expansion of deities' scope, powers, and monitoring abilities.
\end{abstract}

Keywords: animism; belief; cooperation; punishment; religion; ritual 


\section{Three unresolved questions}

Worshiped by the majority of living humans (Pew Research Center, 2017), punitive supernatural agents are ubiquitous and important; they seem to promote cooperation beyond the provincial circle regulated by kinship and reciprocity (Purzycki et al., 2016; Shariff, Willard, Andersen, \& Norenzayan, 2015); and they are associated with the emergence and maintenance of political complexity around the world (Watts, Greenhill, et al., 2015). Yet despite evidence that beliefs in these gods enabled humans' unique levels of cooperation (Norenzayan, 2013; Norenzayan et al., 2016), three basic questions remain unresolved:

First, are supernatural agents believed to enforce cooperation in small-scale societies, especially compared to the supernatural forces of modern world religions? According to a canonical anthropological view, the answer is "no". Tylor (1874/1920, p. 360) endorsed this position when he wrote that "savage animism is almost devoid of that ethical element which to the educated modern mind is the very mainspring of practical religion." Instead, in his appraisal, people in such societies behave morally because of the pressure of "tradition and public opinion, comparatively independent of the animistic belief and rites which exist beside them." Recently however, researchers have returned to the ethnographic record and begun to scrutinize it more closely (Boehm, 2008; Purzycki \& Sosis, 2019; Purzycki et al., 2020; Watts, Greenhill, et al., 2015). Boehm (2008), for instance, coded the ethnographies of 18 forager societies and found supernatural punishment in every society examined. Interestingly though, these punitive forces or gods typically focused on only a few behaviors, often local taboos, and usually lacked the broad, moralistic scope of supernatural punishers in modern world religions, such as karma or the Christian god (White \& Norenzayan, 2019). Better understanding the domains, nature, scope, and intensity of supernatural punishment among hunter-gatherers and horticulturalists is crucial not only for properly characterizing the cultural evolution of prosocial religion, but also for understanding the forces supporting human cooperation in small-scale societies, especially given humans' exceptional levels of cooperation towards non-kin (Hill et al., 2011). ${ }^{1}$

The second key question is: do people really believe in supernatural punishment? Just as people believe that invisible viruses can endanger them and thus buy hand sanitizer to protect themselves (Wiener-Bronner, 2020), do they hold mental representations of supernatural punishers that encourage them to engage in behaviors that would otherwise be perceived as costly? Experimental work suggests that, for believers in world religions, the answer is "yes". Across diverse societies, participants who rated gods as more punitive and knowledgeable were more cooperative with distant co-religionists in economic games (Lang et al., 2019; Purzycki et al., 2016). Moreover, a meta-analysis of 25 experiments showed that whereas religious priming induced prosocial behavior among religious participants, it failed to affect non-religious participants, indicating that the effects of priming depended on participants' beliefs (Shariff et

\footnotetext{
${ }^{1}$ Although recent work on the cultural evolution of religion has focused on the role of supernatural punishment in supporting behaviors favorable to the scaling up of human societies (often the meaning of "morality"), this work has not seriously engaged with the question of how much supernatural punishment exists in small-scale societies or on specifically which behaviors are punished (Norenzayan, 2013; Peoples \& Marlowe, 2012; Roes \& Raymond, 2003). Norenzayan et. al. (2016), for example, write "Whereas there is little dispute that foraging societies possess beliefs in supernatural agents, these spirits and deities are quite different from those of world religions, with only limited powers and circumscribed concerns about human morality."
} 
al., 2015). In lab settings, supernatural belief seems to motivate people to engage in behavior that would otherwise be considered costly.

Despite this growing evidence, many researchers remain skeptical (Baumard \& Boyer, 2013; Boyer, 2018, 2019). They point to evidence showing that religious beliefs affect "reflective" beliefs (those that participants report) but not "intuitive" beliefs (those that affect decisionmaking) (Barrett, 2000). Moreover, most existing empirical evidence comes from experimental rather than naturalistic data, leaving it unclear to what extent beliefs in supernatural punishment affect real-world behavior (although see Shariff and Rhemtulla, 2012; Barro and McCleary, 2006; Edelman, 2009). These gaps are even more pronounced given that almost all aforementioned studies have been conducted with participants in large-scale societies, with little research investigating whether supernatural belief affects naturalistic behavior in small-scale settings.

The final unresolved question is: does observing or participating in ritual reinforce religious belief? Does, for instance, watching a healing ritual promote the belief that a particular supernatural agent causes illness? Scientists have investigated many social effects of ritual, including enabling coordination (Chwe, 2001), transmitting norms (Rossano, 2012), enhancing group identification (Clingingsmith, Khwaja, \& Kremer, 2009; Whitehouse \& Lanman, 2014), and maintaining political hierarchy through demonstrations of power (Watts, Sheehan, Atkinson, Bulbulia, \& Gray, 2016). Researchers have also described how people's social contexts and cognitive architecture contribute to religious belief (Boyer, 2001; Gervais \& Henrich, 2010; Lanman \& Buhrmester, 2017). But these lines of research remain disconnected. With the exception of research on children's belief (Kapitány, Nelson, Burdett, \& Goldstein, 2019; Woolley, Boerger, \& Markman, 2004), very little empirical work has examined the interaction between belief and ritual (although see Barth, 1975). This gap is all the more striking given that some scholars hypothesize that ritual is a critical mechanism for transmitting religious belief (Henrich, 2009; Sosis, 2006; Whitehouse, 1995, 2002, 2004). Without ritual, some propose, the transmission of such beliefs would be impeded by cognitive adaptations for protecting against misinformation.

These questions remain unanswered partly because of a paucity of targeted data on religious practice in small-scale societies. To help fill these gaps, we here present data on a punitive small god: the Mentawai people's water spirit, Sikameinan. As a belief system that includes shamanism, ancestor spirits, and an animist worldview (Loeb, 1929b, 1929c; Schefold, 1988; Singh \& Henrich, 2020), Mentawai religion shares features with the traditional religions of many small-scale societies, including those of hunter-gatherers (Boyer, 2019; Peoples, Duda, \& Marlowe, 2016; Rossano, 2007; Singh, 2018).

We learned about Sikameinan after M.S. first began conducting fieldwork in Mentawai in 2014. Through informal interviews in the Sarereiket region and Schefold's $(1982,1988)$ reports about the Sakuddei clan (which originally migrated from Sarereiket), we learned that people claim that a water spirit attacks individuals who refuse to share and that, in response, shamans remove the water spirit from people's houses. These findings inspired the much more comprehensive investigation reported here. Synthesizing interview responses across four regions, behavioral data on healing ceremonies, and primary ethnographic observation, we address the three questions just outlined while presenting a rich ethnographic case study of a punitive small god in an animist tradition. 


\section{Ethnographic context}

\subsection{General background}

The Siberut Mentawai live in the river valleys of Siberut Island (Indonesia), the largest island of the Mentawai Archipelago (4,030 km²; about $150 \mathrm{~km}$ west of Sumatra) (Tulius, 2012) (Figure 1). The island is covered by at least 11 major rivers, each branching into dozens of smaller waterways. Given the distance between rivers and a history of headhunting, people infrequently traveled to other rivers, driving cultural differences among people living in distinct river valleys (Schefold, 2007). We refer to the set of communities who speak a common dialect and live in the same river valley as a cultural region. The research reported here draws on interviews and observations conducted in four cultural regions of southern Siberut: (1) Sabirut (villages of Maileppet and Muntei), (2) Sarereiket (villages of Buttui and Ugai), (3) Silaoinan (village of Salappa), and (4) Taileleu (village of Taileleu) (Figure 1).

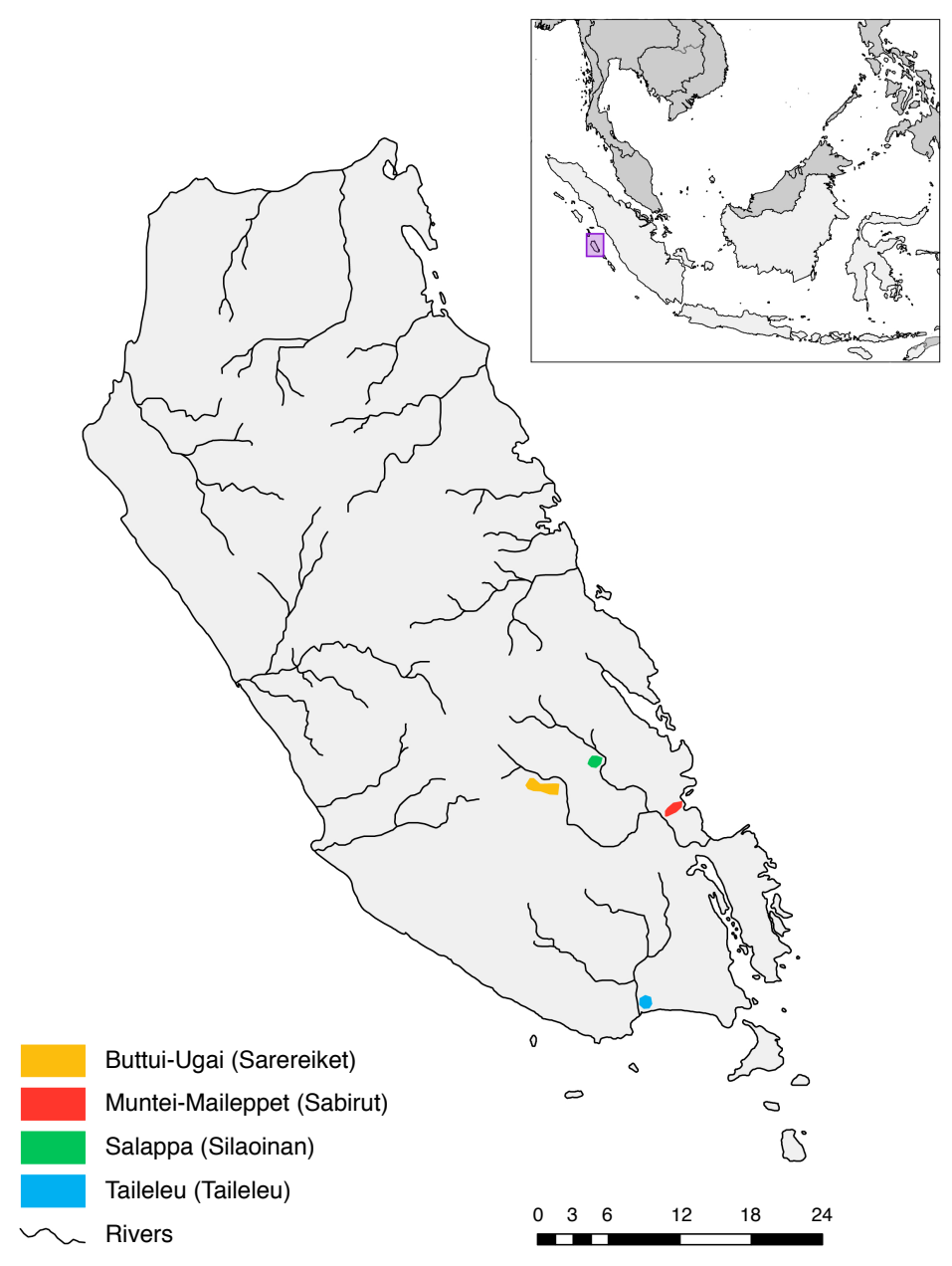

Figure 1. Siberut Island, the largest island of the Mentawai Archipelago (Indonesia). The different study sites are colored. The legend shows the villages studied with the cultural region in parentheses. Indonesia is light gray in the inset, while other countries are dark gray. 
The Mentawai are organized into patrilineal clans (known as uma), traditionally residing either in longhouses (also known as uma) or small houses nearby (Schefold, 1988; Tulius, 2012). Following settlement programs by the government, most people shifted to villages (barasi), which host schools, mosques, churches, and clinics. Settlement villages alter residence patterns by placing families in close proximity and positioning clans much closer than they traditionally lived. Nevertheless, many families maintain several residences, traveling between a house in the forest, where they tend to pigs and conduct ceremonies, and a house in the settlement village. Some families, typically those of shamans, spend most or all of their time in these forest residences. Families with school-age children, meanwhile, tend to remain in settlement villages.

The Mentawai living on Siberut are rainforest horticulturalists. The staple of their diet is starch extracted from the sago palm, but they also cultivate taro, cassava, and a wide assortment of fruit trees, including coconuts, bananas, durian, rambutan, and mangos. They raise pigs and chickens, as well as ducks, geese, cows, and buffalo, although those in the latter category are recent introductions and, with the exception of ducks, rarely owned by Mentawai people. They supplement their diet with foraged foods, such as deer, ferns, shrimp, frogs, primates, wild pigs, and sago grubs.

Market foods are ubiquitous on the island and, in the case of rice, noodles, sugar, tea, and coffee, highly preferred. People seek out wage labor opportunities to acquire these goods, pay for school fees, and build larger houses, among other ends. In the villages of Ugai and Buttui, where M.S. has to date conducted 11 months of fieldwork, the main means of acquiring cash, in descending frequency, include: selling agricultural products (e.g., bananas, cacao), working on development projects (e.g., road-building), finding opportunities off-island (e.g., in Sumatra), and, most enviably, working as a government official or teacher. Several families ( 5) also host tourists interested in exotic homestays ("tribal tours"). Still, hunting and subsistence farming-in particular, sago horticulture - serve as the basis for the Mentawai people's livelihoods, especially for people living in the island's interior. As of 2011, 75\% of individuals in Matotonan (a large village in Sarereiket) received a quarter or less of their food and drink from the market, while 94\% reported that they would not be able to survive without sago (Indigenous Education Foundation, 2012).

\subsection{Sharing meat}

As will become clear, the domain of cooperation most relevant to the punitive spirit Sikameinan is meat sharing. Meat sharing is regulated by a set of norms (Schefold, 1982). People are expected to share meat in at least four circumstances: (1) when inviting help in a collaborative endeavor, such as building a house, making a canoe, or dragging a canoe down from the forest to the village (Figure 2A); (2) when sharing the spoils of a collaborative hunt (Figure 2B); (3) when hosting a ceremony, such as a healing ceremony or after building a house (Figure 2C); and (4) after receiving a large package of meat, such as from the three previous contexts as well as from a bride payment, a penalty for a crime, or a solitary hunt (Figure 2D). With some exceptions, people are expected to distribute portions that are equal, not only in size but also in the kind of meat, such as fat, lungs, and skeletal muscle, included in each portion (Figure 2).

Meat sharing is, to some extent, altruistic. In the first three contexts just listed, sharing is enforced through mechanisms such as reputation or reciprocity, because other people know 
whether a person shared. But the fourth context-sharing large packets-is vulnerable to cheating. People can take advantage of norms about sharing with clan members and close friends. They can hide their own prizes while accepting the gifts of others. Or they can lie about how much they received, handing out smaller or fewer shares. In many cases, meat sharing subject to exploitation.
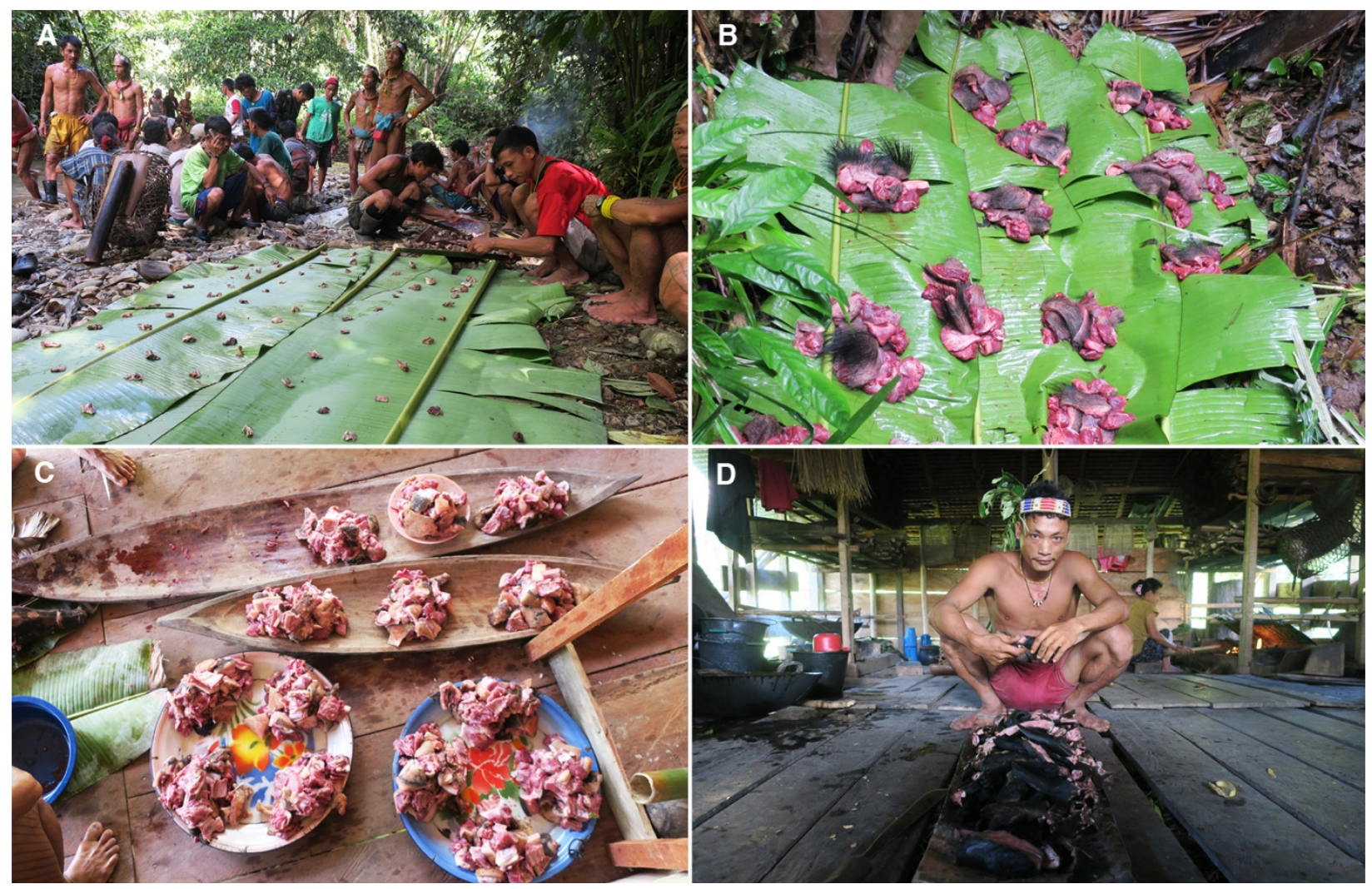

Figure 2. Four contexts of meat sharing (photographs taken in 2017; credit M. Singh). (A) People who request help in a collaborative effort compensate helpers with food, including meat. This picture shows individuals divvying up portions of taro and pig to share with men who helped drag canoes from the forest, where they were made, to the settlement village. (B) People who cooperatively hunt share the rewards. This pictures shows the meat of a hunted boar divided among all of the families who helped hunt and butcher it in the forest. (C) People share meat during ceremonies. This picture was taken during a ceremony for inaugurating a new house. It shows portions of meat for both attendees and sharing partners who could not attend. (D) People share meat when they receive a large packet, including from any of the previous three contexts as well as from bride payments, penalties of crimes, and solitary hunts. This picture shows a man posing with several monkeys he had just hunted. Later, he divided up the meat to share.

\subsection{Religion in Mentawai}


The indigenous Mentawai religious system is known as Arat Sabulungan. Arat Sabulungan is animist: Every thing is believed have a soul (Delfi, 2013; Loeb, 1929b; Schefold, 1988). Pigs, plants, wild deer, tiny rats, new canoe motors, even the different materials composing a house all are animated (although not necessarily alive) (Reeves, 2000). All have spiritual essences that can be inadvertently disturbed, and which must be appeased to protect against misfortune. Humans have souls, too, and a person is said to fall ill when their soul wanders too far from their body. A person can also purportedly become ill if they (1) are attacked by sorcery, (2) violate taboos, (3) inadvertently encounter spirits in the forest or while bathing, (4) are scratched by the forest spirit Silakikio, (5) are attacked by the water spirit Sikameinan, or (6) are inadvertently hit by magic that has been prepared for non-malicious purposes. People are also said to fall ill if they eat irregularly or if a terrible, deadly illness sweeps through a community.

The traditional healers in Mentawai are sikerei (shamans), a class of men set apart by their ability to see spirits (Loeb, 1929c; Singh \& Henrich, 2020). As healers, sikerei are experts in herbal medicine and the special songs used for communicating with souls and spirits. A man hoping to become a sikerei must host a series of ceremonies, find another sikerei to teach him songs and herbal medicines, and have his eyes magically treated. In some cultural regions, sikerei are marked by their continued use of the loincloth and their full-body tattoos.

Sikerei treat ailments in healing ceremonies called pabetei. The family hosting the ceremony sacrifices pigs or chickens, which are shared with the sikerei (as a kind of payment) and the patient's kin. Healing ceremonies are like doctor's appointments: All of them share common elements, but each is also geared to target particular ailments. There are, for example, special treatments for souls that have wandered too far, illness caused by Silakikio, and removing Sikameinan for a patient's house. The intervention regarded as most paradigmatic of the sikerei institution is lajo simagre, an all-night treatment during which sikerei dance and summon beneficent spirits. As these spirits approach the dancing shamans, they enter trance (gobok). Governmental programs and missionaries have both affected the religious landscape of Mentawai. Arat Sabulungan was officially forbidden in 1954 as a part of the West Sumatran government's policy of modernization (Bakker, 1999; Schefold, 1998). In the 1960s, the Indonesian government identified the Mentawai as suku terasing, an "isolated ethnic group" that had to be brought into the fold of the Indonesian nation. By the 1970s, the state began concerted efforts at acculturation in the island's interior. Shamanism, tattooing, teeth-sharpening, and other indigenous practices were prohibited. Longhouses were demolished. Partly as a result of these efforts, shamanism and other traditional elements declined in the Mentawai islands. Yet they survived in interior areas of Siberut, likely due to the resistance of local clans, people fleeing to ever-more-remote areas, and the difficulty of encouraging officials to stay in villages and enforce the rules (Bakker, 1999; Hammons, 2010). After 1987, the government eased off the acculturation efforts, allowing indigenous religious practice to continue largely unmolested (Bakker, 1999).

The German Royal Missionary Society (Protestants) established the first mission station in the Mentawai Archipelago in Sikakap, on the island of North Pagai (Hammons, 2010). The first missionary took up residence in 1901, and the first conversion occurred in 1915. In 1932, the first Protestant mission station was established on Siberut, in Maileppet (Sabirut region). Following World War II, Catholic Italian missionaries established a station on the island, also in 
Sabirut, in Muara Siberut ${ }^{2}$. But Christian missionaries were slow to reach many parts of the interior. The first outside religion to arrive in Buttui and Salappa was not Christianity (or Islam, which has taken the longest to reach the interior), but Baha'i, which came to Siberut in the mid1950s (see Rudito, 2001). Catholicism eventually arrived in Both Buttui and Salappa (dates are uncertain), but, at least in the case of Buttui, it was permissive of indigenous religion, likely because these communities actively resisted acculturation (the people of Buttui avoided the government settlement program until the early 2010s, when the barasi was built there). For example, when the Catholic priest who worked in Buttui established a small jungle school for children to learn to read and write, he named it Parurukat Toga Sikerei Butui, or "Meeting of the Buttui Shamans' Children".

Islam has spread more slowly in Siberut. When, in 1954, government officials gave groups of Mentawai people the option to choose between Protestantism and Islam, most nominally chose Protestantism because it permitted them to eat pigs (Bakker, 1999). More recently, Islam has targeted areas that have otherwise experienced less missionary activity. It arrived in Buttui around 2012 with the development organization Yayasan Aksi Peduli Bangsa (roughly, "Foundation for Nation Caring Action") (Aksi Peduli Bangsa, 2020), coinciding with the departure of the Catholic priest and the disappearance of his jungle school. The development organization built a mosque, housing for teachers, a small shop, a cement football court, and a single-room schoolhouse that, since the 2016 construction of a primary school (Sekolah Dasar) in Buttui, has served as a kindergarten (Taman Kanak-Kanak). Several families in the clans Salakkirat and Sabettiliake converted when the organization first arrived, likely to receive gifts and allow their children to attend school. In 2017, while M.S. was conducting fieldwork, more families in Salakkirat converted, as well as families in the clans Tasirikeru and Satairarak. Many of the families that converted were those that continued to live in the surrounding forest. The same development organization seems to also have spread into Salappa in the region Silaoinan.

This discussion of how missionaries and the state have affected the Mentawai religious landscape demonstrates just how varied the four regions' experiences have been. The differential effects of these programs are clear when comparing villages in Sabirut (a coastal region where enforcement and missionizing were easier) to those upriver in Sarereiket (a region in the interior). In 2017, M.S. counted fewer than 5 shamans across two Sabirut villages (Maileppet, Muntei), while he has found at least 90 shamans across four villages in Sareireket (Rogdog, Madobag, Ugai, Buttui). Studying regions with such varied experiences is useful because it allows us to determine to what extent our results may be influenced by contact with the state and Abrahamic religions. If we identify similar beliefs across four regions that vary both in the kind of outside exposure (e.g., Islam, Catholicism, Protestantism, Baha'i) and its degree, we can more confidently conclude that those beliefs predated those forces. We return to this point in the discussion.

\section{Data collection}

Our report draws on three sources of data: ethnographic interviews about Sikameinan conducted with 96 participants across four cultural regions of southern Siberut; systematic data covering 66

\footnotetext{
${ }^{2}$ Siberut is the name of the island, Sabirut is the name of a region and dialect in South Siberut, and Muara Siberut is the administrative center of South Siberut.
} 
healing ceremonies, most of which occurred in the Buttui-Ugai region of Siberut in 2017; and participant observation occurring over 11 months in the Buttui-Ugai region.

The Harvard University Committee on the Use of Human Subjects approved this research project. All participants provided verbal informed consent before the study. All analyses and cleaned data are available online on the OSF project website online at https://osf.io/bjq6f/.

\subsection{Sikameinan interviews}

M.S. interviewed participants about Sikameinan in 2017 as part of a larger cross-regional study of cultural beliefs in southern Siberut. All interviews were conducted in the Mentawai language by M.S. Interviews were conducted in the villages of Buttui and Ugai (Sarereiket) $(n=40)$, Muntei and Maileppet (Sabirut) ( $\mathrm{n}=19)$, Salappa (Silaoinan) $(\mathrm{n}=21)$, and Taileleu (Taileleu) ( $\mathrm{n}$ =16) (Figure 1). We aimed to interview those participants living in the same village in as few days as possible and visited different sections of each village on different days. We selected participants opportunistically and made efforts to both (1) interview participants privately and out of earshot (such as in the participant's house or a small building to which participants were invited) and (2) prevent participants who had completed the interview from discussing it with other individuals (such as by having a research assistant sit with participants as they waited to be interviewed).

Interviews consisted of demographic variables (name, age, patrilineal clan, village of residence, village of origin, spouse's clan, religion, and years of schooling), as well as surveys on shaman taboos and Sikameinan. M.S. prepared the Mentawai translation of the interview script with the assistance of a native speaker. With the exception of eight participants in Sarereiket, all participants were asked the seven questions about Sikameinan in the same order:

1. Number -

English: According to you, how many spirits are there? One? Two? Many?

Mentawai: Menurut ekeu, piga simagrena e? Ale sabbek? Ale rua? Ale maiggi?

2. Sex -

English: According to you, is the spirit female? Male? Both?

Mentawai: Menurut ekeu, ale sinanalep ia simagrena e? Ale simateu? Ale ka duada?

3. Location -

English: Normally, where does the spirit live?

Mentawai: Biasania, kapa ilelek simagrena e?

4. Reason for attack -

English: Why does the spirit strike us?

Mentawai: Ponoili iorag ita simagrena e?

5. Method of attack -

English: When it strikes us, what does the spirit do?

Mentawai: Kana iorag ita, kipa ikut simagrena e?

6. Misfortune -

English: How is the injury/illness when it strikes us?

Mentawai: Kipa besitta kana iorag ita simagrena e?

7. Ritual objects -

English: When they do the meinan ritual, what objects do they put out?

Mentawai: Kana dakut meinan, ponia daudutnakke alaket e? 
Participants were afterwards invited to draw Sikameinan.

Responses to these questions were recorded during the interviews and later translated, cleaned, and binned. M.S. later translated responses to English, receiving assistance from other Mentawai people and, when necessary, other Mentawai experts (Maskota Delfi, Rob Henry, Juniator Tulius). Supplementary Tables S1-S7 present participants' responses for each of the seven questions.

All analyses were conducted in R 3.4.3 (R Core Team, 2015). As a part of our analysis, we calculated the agreement among respondents about a given question (represented here with $a$ ) according to the following formula:

$$
a=\frac{\sum_{i=1}^{s} p_{i} n_{i}}{\sum_{i=1}^{s} n_{i}}
$$

where $n_{i}$ is the number of respondents who gave the $i$ th answer, $p_{i}$ is the proportion of respondents who gave the $i$ th answer, and $s$ is the total number of types of answers. See the supplemental materials for more details about his formula.

\subsection{Healing ceremonies}

M.S. interviewed the patients of healing ceremonies or their family members in 2017. M.S. prepared the Mentawai interview script with the assistance of a native speaker. We either interviewed patients after attending or having heard about a healing ceremony or asked people to tell us about their or a family member's most recent healing ceremony. All interviews were conducted along the Rereiket River with most occurring in Ugai and Buttui. Interviews were conducted in the Mentawai language.

Respondents were asked about the treatments in the healing ceremony, the number of pigs and chickens sacrificed, the length of the ceremony, and which shamans provided care. Participants were also asked about the illness, such as what the ailment was, how long it had gone on, whether they had hosted a healing ceremony for it before, why they believed it to have occurred, which other treatments they had pursued, and whether the ceremony had worked.

When possible, participants' responses were verified in one or more of the following ways: (1) M.S. attended the healing ceremony; (2) M.S. verified details with other community members, preferably one of the sikerei said to administer the ceremony; or (3) M.S. reinterviewed the participant or another family member. In total, 90 interviews were conducted about 77 healing ceremonies and 75 bouts of illness (some healing ceremonies targeted several bouts of illness, such as when siblings or spouses were healed, while some illness bouts were healed in several successive ceremonies). Eleven healing ceremonies and 10 bouts of illness were removed from analyses because no ceremony was actually conducted $(n=1)$, other observers denied that a ceremony was conducted $(n=4)$, the participant admitted to not remembering details clearly $(n=3)$, there were discrepancies when the participant was interviewed again $(n=$ $2)$, or other parties disagreed about noteworthy details $(n=1)$.

Responses to the questions were recorded during the interviews. M.S. later translated responses, receiving assistance from other Mentawai people or experts when necessary. All analyses were conducted in R 3.4.3 (R Core Team, 2015). 


\section{Sikameinan}

Throughout southern Siberut, people describe a water-dwelling spirit that causes illness, is appeased in shamanic healing ceremonies, and is often referred to as Sikameinan or meinan (derived from kameinan, "aunt"). The spirit's other names include Silapualai (derived from alai, "hair") and Sibeulepei ("that with big clothes"), although these names are more variable than Sikameinan and some respondents regarded them as distinct spirits. In line with these names, people often describe Sikameinan as having long hair and wearing big clothes.

Almost all participants drew a close connection between Sikameinan and crocodiles. In fact, the spirit is often known by the word for crocodile, sikaoinan ("that which is in water") (e.g., Schefold, 1982, 1988). Many participants considered Sikameinan to be the spirit of a crocodile or to look like a crocodile (see Figure 3 for some illustrations). Those participants who considered Sikameinan to be more human-like often considered the spirit to be a friend of crocodiles, to order them to attack humans, or to use a crocodile as its "canoe" (abak) (see Supplementary Table S8 for some participants' descriptions).
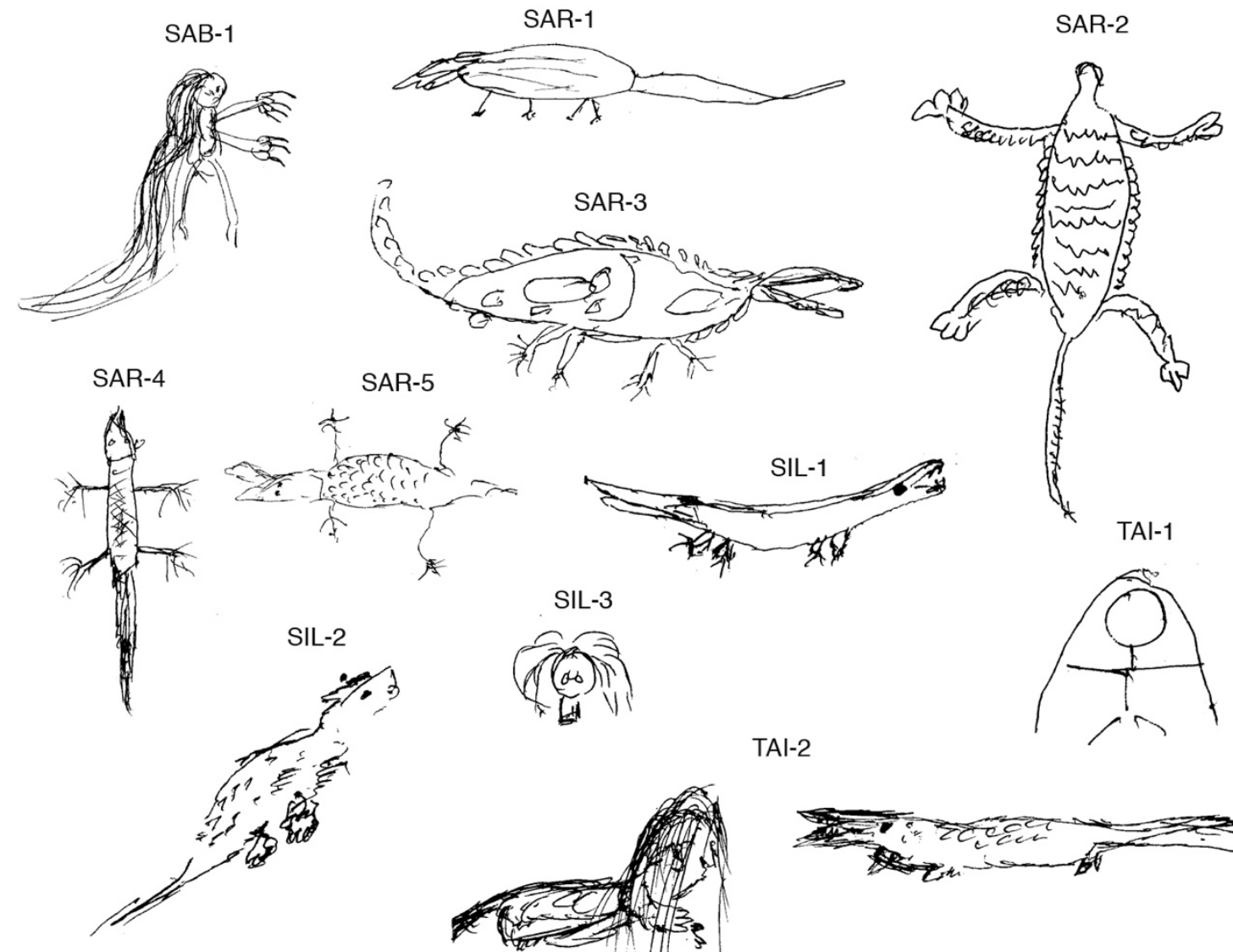
the physical body of Sikameinan (a crocodile) and its soul (a long-haired figure with the torso and limbs of a crocodile).

\subsection{Sikameinan has moral concerns, but they are limited in scope and domain}

Across four cultural regions of southern Siberut, participants near-unanimously reported that Sikameinan attacks people who fail to share (Figure 4A; Supplementary Table S4). Moreover, participants who specified which items must be shared almost exclusively mentioned meat, although a tiny minority mentioned other items including money and kat (edible plant food) (Figure 4B). We did not collect data on who food must be shared with, but food-sharing norms in Mentawai dictate that people share with social intimates, especially clanmates, affines, and neighbors who live nearby (Hammons, 2010; Schefold, 1982). Sikameinan has moralistic concerns, but they are limited in domain (sharing meat) and scope (clanmates and other relatives). 

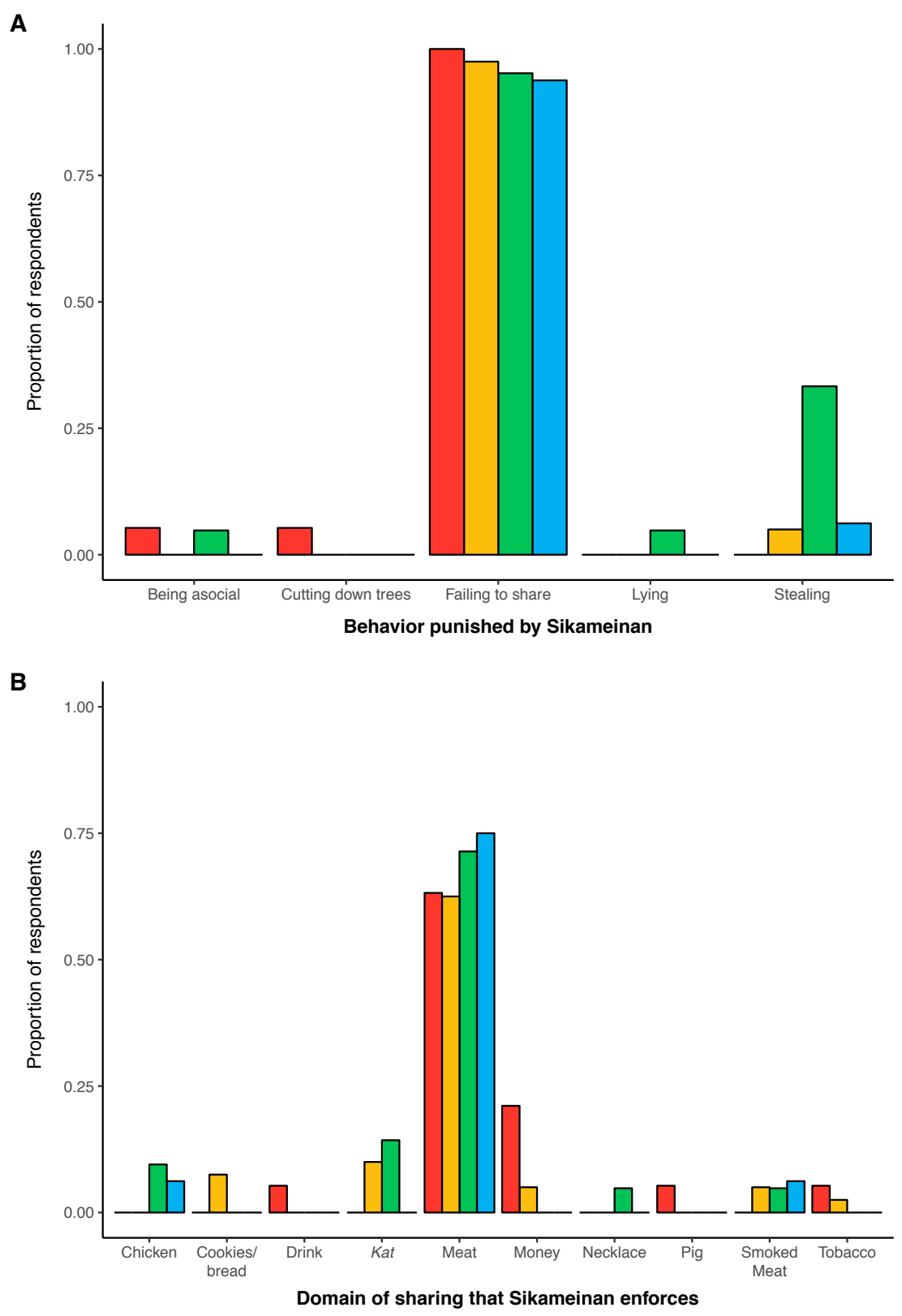

Figure 4. The reasons Sikameinan attacks people, according to free responses $(N=96)$. Colors correspond with cultural regions: red $=$ Sabirut; yellow $=$ Sareireket; green $=$ Silaoinan; blue $=$ Taileleu. Panel A shows the proportion of respondents reporting different reasons that Sikameinan attacks people. Panel B shows the proportion of respondents reporting different domains of sharing that Sikameinan enforces.

Unprompted, respondents sometimes suggested that the fear of Sikameinan causes people to share. One woman noted that the Mentawai have no need for foreign religions and moralistic prescriptions because Arat Sabulungan (indigenous Mentawai religion) already deters wrongdoing. The fear of sorcery prevents people from stealing, she noted, and Sikameinan ensures that they share. 
An older woman also observed the instrumental effect of Sikameinan: "That's why we give meat to other people; that's why we give plant-food. We give them plant-food; we give them meat. They see our food, we give it. [Otherwise, Sikameinan] carries us to the bottom [of the river]. The body [of the crocodile] - not just a spirit. To the bottom it carries us."

\subsection{People suspect Sikameinan after many kinds of harms}

People believe that Sikameinan watches them. When asked where the spirit lives, most respondents said that Sikameinan lives in water, such as the river or the small puddles that collect in broken bamboo (Figure 5; Supplementary Table S3). Several respondents reported that it drifts through the air like wind; one person compared it to the regional government - "wherever we go, it knows." Other respondents said that it lives in people's houses. 

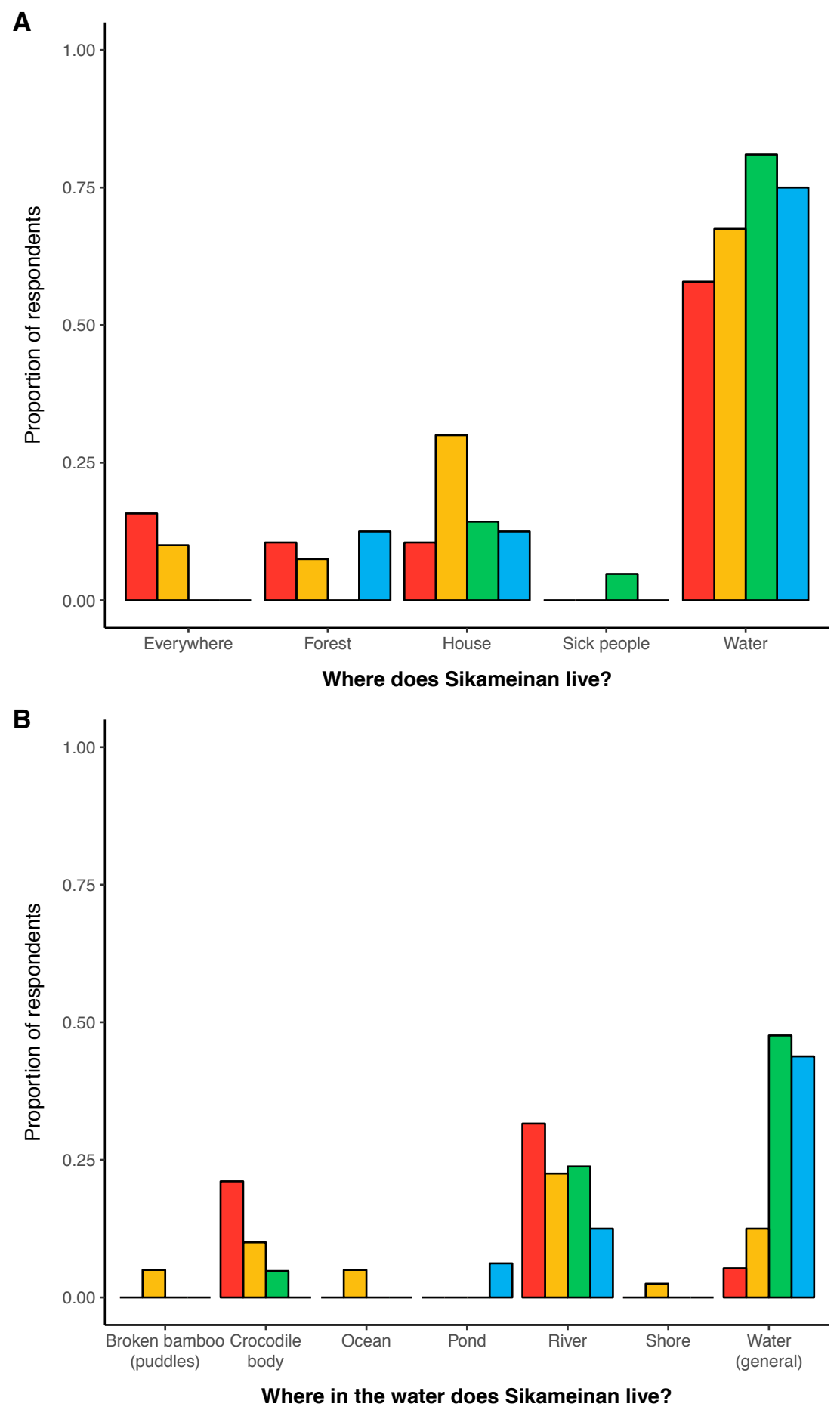

Figure 5. Where Sikameinan lives, according to free responses $(\mathrm{N}=96)$. Colors correspond with cultural regions: red $=$ Sabirut; yellow $=$ Sareireket; green $=$ Silaoinan; blue $=$ Taileleu . Panel A shows the proportion of respondents reporting different locations where Sikameinan lives, aggregating responses about water. Panel B shows the breakdown of different responses about water. 
When Sikameinan sees someone refusing to share, it attacks. It enters its victim's house and climbs onto a cross beam. It radiates its illness-causing energy (bajou), scratches its victim, or weighs down on top of them, making it hard to breathe. Alternatively, it might wait for the stingy person or their family members in the river. When its target arrives, Sikameinan attacks them as a crocodile, or it directs a crocodile to attack them, or it pulls them to the bottom and drowns them (see Supplementary Figure S1 and Supplementary Table S5 for participants' responses about how Sikameinan attacks; see Supplementary Figure S2 and Supplementary Table S6 for participants' responses about the kinds of illnesses and injuries Sikameinan causes).

People sometimes connect others' misfortunes to their stinginess and Sikameinan's retribution. In 1988, Bakels was told about a crocodile that carried off a small boy (Bakels, 1994). The animal's violence was blamed on the boy's mother's stinginess. Similarly, when a boy drowned in August 2017 in a community where M.S. was conducting research, people covertly discussed possible reasons. The leading explanation that developed was that Sikameinan attacked after the boy's parents failed to share their growing wealth.

\subsection{People pay costs for shamans to remove Sikameinan in a dramatic, public ritual}

When it's concluded that a patient's illness is caused by Sikameinan, the sikerei conduct a special ceremony, known most frequently as meinan, to remove it from the house and return it to the river. The sikerei assemble in the patient's house or the patient's clan's longhouse, usually with the patient's family. They put out objects that will attract Sikameinan, such as fabric and a fishing net (Figure 6A; Supplementary Table S7). They publicly acknowledge that the patient or their family did not share, but they promise Sikameinan that this was not intentional. The patient and their family members apologize, assuring Sikameinan and any observers that they will share in the future. 

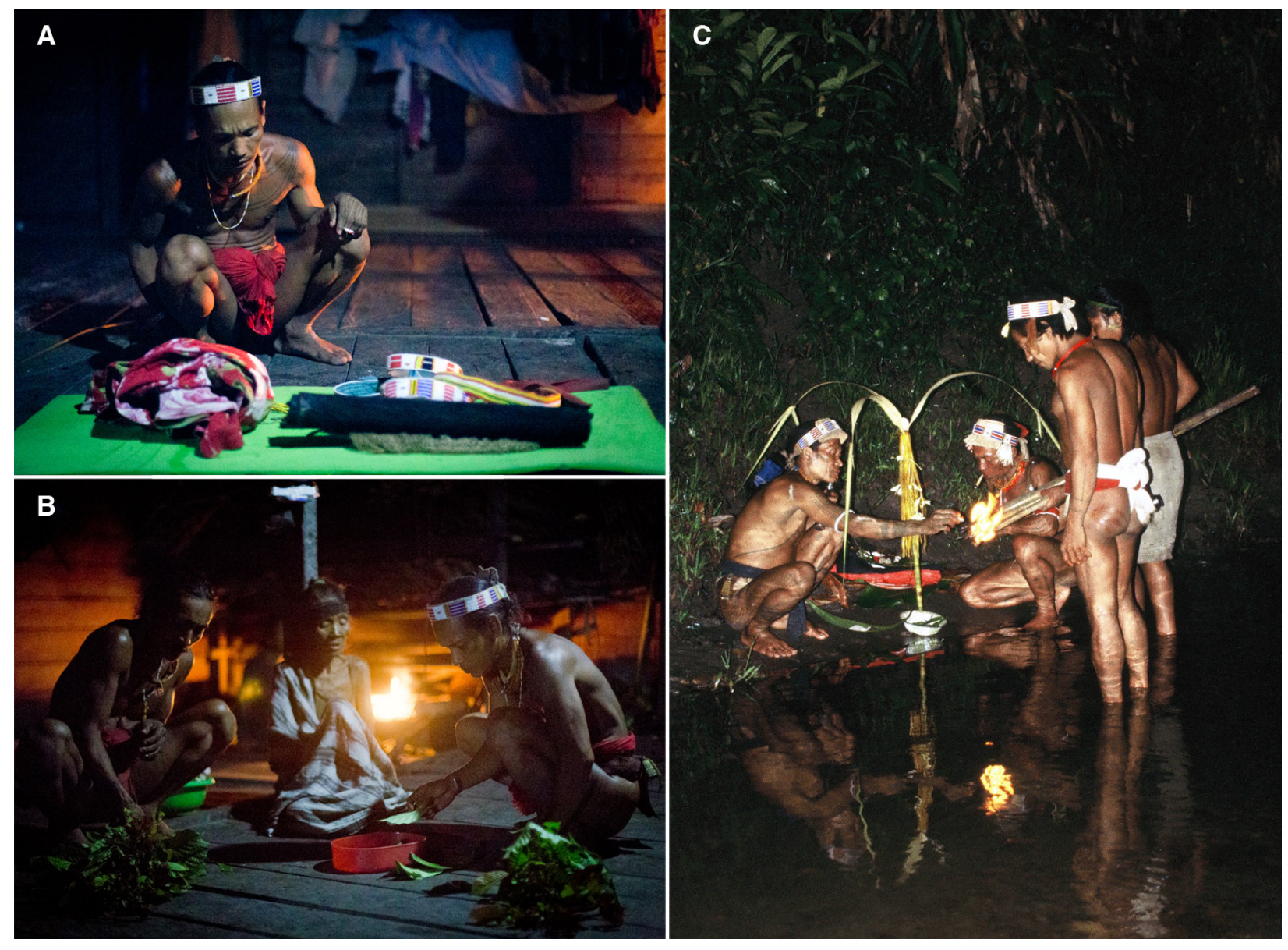

Figure 6. Sikerei (Mentawai shamans) conduct ceremonies to remove Sikameinan from a patient's house. (A) A sikerei presents items to attract Sikameinan, including a necklace, fabric, and a luat (shaman headband) (photo taken in 2019; credit/copyright Rob Henry, Indigenous Education Foundation). (B) The sikerei invite Sikameinan into a small container of water (2019; credit/copyright Rob Henry, Indigenous Educatoin Foundation). (C) Sikerei prepare to release Sikameinan into the river (1978; credit/copyright Reimar Schefold).

The sikerei then use special songs to lure Sikameinan into a small basin of water (Figure 6B). These songs are considered powerful ways of inviting Sikameinan, and for that reason, people are forbidden from singing them outside of the Sikameinan ceremony.

Once Sikameinan is captured, the sikerei carry it to the river. They hold the basin steady to prevent Sikameinan from tumbling out. They bring the lavish gifts and a small food item, such as smoked meat or piece of chicken. Finally, they release Sikameinan into the water (Figure 6C).

There are three noteworthy points about this ceremony:

1. The ceremony is costly. The costliness of healing ceremonies provides evidence that people sincerely believe in Sikameinan. If they did not believe that Sikameinan had harmed them, they would presumably be less motivated to incur costs for shamans to come and banish the spirit. 
There are two ways in which ceremonies are costly. First, the family hosting the ceremony must provide food for the shamans and other family members. This means preparing taro, sago, sweetened beverages, and, most importantly, meat.

The consensus is that the "price" of a meinan ceremony is 1 or 2 chickens. Examining the subset of healing ceremonies that included only the meinan ceremony (or the meinan ceremony and a treatment for the spirit-illness kisei, which is said to require no additional sacrifice), we found that the number of animals sacrificed varied from no chickens (when a shaman conducted the ceremony privately for his sick child) to a large female pig and 2 chickens (a large female pig is roughly equivalent in value to ten adult chickens) (see Table 1 for the list of ceremonies and their accompanying sacrifices). Although the family also consumes the food, (1) they must share it with more people than they would if they killed it in private, (2) they give up other opportunities to use the animals (such as other household ceremonies or, in the case of pigs, bride prices or penalties for crime), and (3) they give up the best portions of the meat to the shamans.

Table 1. Prices of twelve healing ceremonies that either only included the ritual for removing Sikameinan (S) or included that ritual and a treatment for kisei (K), which is said to require no additional sacrifices. The PBID refers to the identifier in the dataset, available online. The estimated value is listed in thousands of Indonesian Rupiah (IDR); on 1 July 2017, 1000 IDR was equivalent to about 0.075 USD. Note that not all chickens are equivalent in value. For PB03, the patient reported two sets of responses on two different occasions; both are reported in the table.

\begin{tabular}{llll} 
PBID & Animals sacrificed & $\begin{array}{l}\text { Estimated value } \\
\text { (thousands of IDR) }\end{array}$ & Interventions \\
\hline PB30 & 1 large female pig and 2 chickens & 1010 & $\mathrm{~S}$ \\
PB42 & 1 medium-sized pig and 2 chickens & 660 & $\mathrm{~S}$ \\
PB66 & 1 medium-sized pig and 4 chickens & 700 & $\mathrm{~S}$ \\
PB03 & 2 chickens // 1 rooster & $160 / / 100$ & $\mathrm{~S} / / \mathrm{S}, \mathrm{K}$ \\
PB39 & 2 chickens & 160 & $\mathrm{~S}, \mathrm{~K}$ \\
PB40 & 2 small pigs & 350 & $\mathrm{~S}, \mathrm{~K}$ \\
PB41 & 2 chickens & 160 & $\mathrm{~S}, \mathrm{~K}$ \\
PB51 & 0 [shaman healed his sick child] & 0 & $\mathrm{~S}, \mathrm{~K}$ \\
PB57 & 1 small pig, 1 chicken, and 1 duck & 330 & $\mathrm{~S}, \mathrm{~K}$ \\
PB60 & 1 medium-sized pig & 500 & $\mathrm{~S}, \mathrm{~K}$ \\
PB63 & 2 chickens and 1 duck & 235 & $\mathrm{~S}, \mathrm{~K}$ \\
PB73 & 1 chicken & 80 & $\mathrm{~S}, \mathrm{~K}$
\end{tabular}

The second important way in which hosting the ceremony incurs costs is that it redirects resources from other treatments. Of 62 bouts of illness for which we have information, $63 \%$ $(39 / 62)$ were also treated with herbal or magical remedies. For $50 \%$ of those illnesses (31/62), the patient or their family also sought healthcare at a village health post (Poskesdes) or community health center (Puskesmas). Obtaining herbal remedies and healthcare at a clinic incurs costs, including the time involved in collecting herbs or the price of the medicine. Patients also visit 
alternative health providers, such as Muslim or Christian healers; these visits also consume time and resources. By spending half a day organizing and paying for a Sikameinan ceremony, families lose the opportunity to pursue other treatment options. People's willingness to pay for Sikameinan ceremonies, especially considering the opportunity costs, suggests that representations of supernatural punishment motivate people to engage in behavior that would be perceived as costly were they not to hold those beliefs.

2. Elements of the ceremony reinforce belief. Two aspects of the Sikameinan ceremony seem to reinforce beliefs that Sikameinan is responsible for illness. First, hosting a healing ceremony exhibits the features of a CRedibility-Enhancing Display (CRED) (Henrich, 2009). It is a behavior that would only be sensible if a person held a given belief. In this case, the ceremony is sufficiently costly that someone should host it only if they believe that Sikameinan may have caused illness. The ceremony thus reliably indicates belief, increasing the likelihood that others will adopt similar representations about Sikameinan.

The second element of the Sikameinan ceremony that should reinforce others' beliefs is that it features prestigious individuals speaking to the spirit. Sikerei are said to be uniquely capable of seeing spirits, including Sikameinan. They are also trusted for their expertise, especially in Mentawai religious practice (see Supplementary Study 1 and Supplementary Figure S3), and are frequently called to intervene in conflicts, evidencing their status and people's trust in their decisions. The Sikameinan ceremony features these reputable men speaking to the spirit, apologizing to it, coaxing it into a container, and then releasing it into the water. This performance may further reinforce that Sikameinan is real and to be taken seriously.

3. The natural course of recovery reinforces belief. Eventually, most people recover from their illness. The timing of their recovery influences their theories about which treatments were effective and, in turn, what originally caused the illness. For example, a patient who recovers soon after shamans remove Sikameinan from their house might attribute their improvement to the ritual and thus their illness to Sikameinan's attack. This seems to happen: Of families that paid for a Sikameinan ritual, 11\% later reported that Sikameinan was a reason the patient became ill. In total, 7 of 65 illness bouts were thought to have been caused by Sikameinan after the patient recovered.

\subsection{People infer features of Sikameinan from ceremonies}

Sikameinan ceremonies occur often. In our sample of 66 healing ceremonies, nearly all of which occurred in a single year, 46 included a Sikameinan ceremony - more than any other special intervention (Figure 7). Although it remains uncertain how often individuals attend the Sikameinan ceremony, we counted 19 Sikameinan ceremonies in a community of 262 individuals. Assuming that each ceremony draws 20 observers, we estimate that an individual has a $78 \%$ chance of attending a Sikameinan ceremony in a given year. 


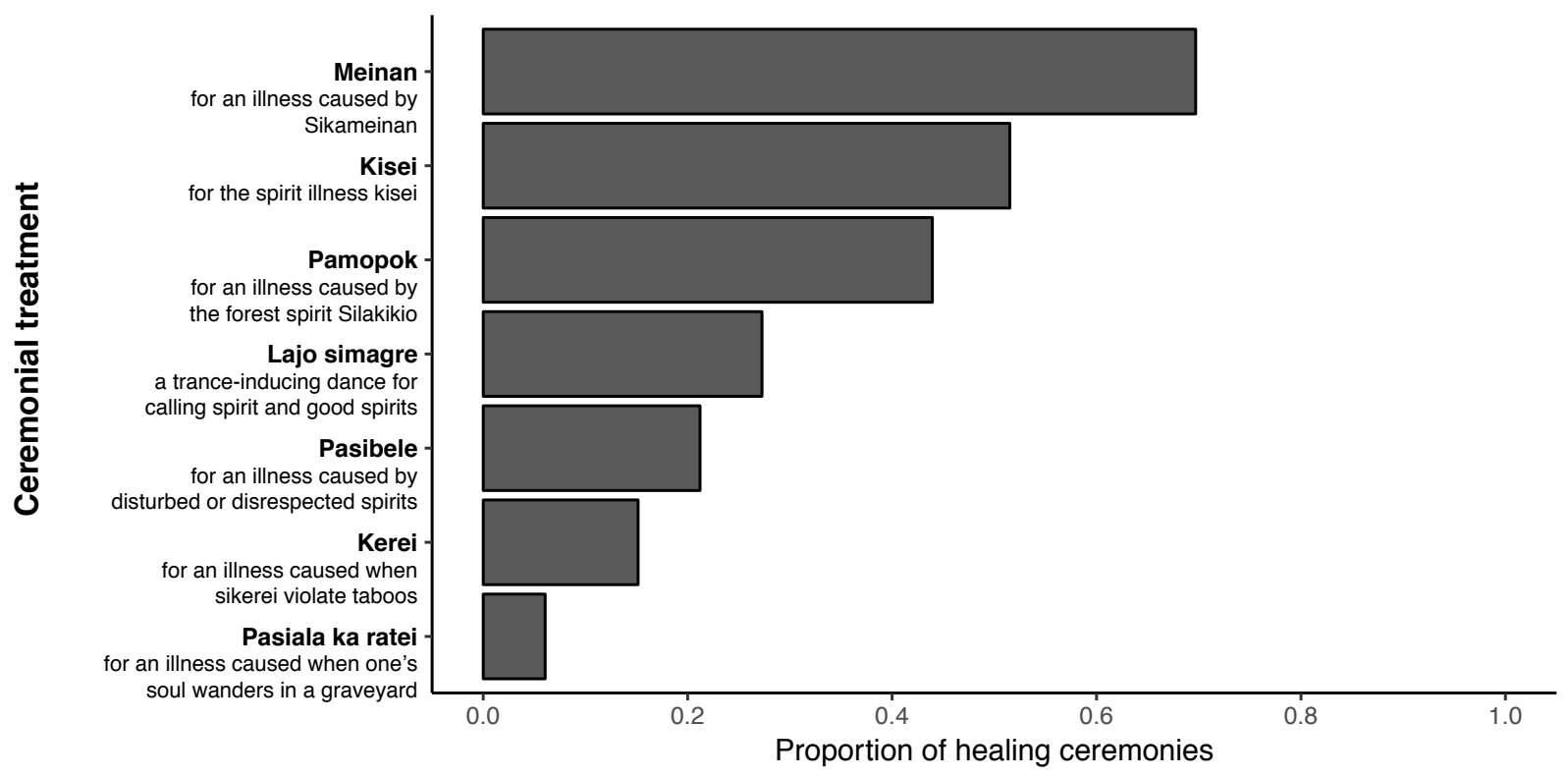

Figure 7. The proportion of healing ceremonies featuring different treatments. Treatments used infrequently $(>0.05)$ have been removed.

Two lines of evidence suggest that these ceremonies transmit beliefs about Sikameinan:

First, in explaining their answers, respondents explicitly drew inferences from the Sikameinan ceremony, such as that Sikameinan lives in water because shamans place it in water, that it lives near the ceiling because shamans look there during ceremonies, and that it is female because shamans refer to it (her) as "aunt".

Second, of those features of Sikameinan we systematically studied, all of the most widely shared beliefs are represented in the ritual or can be readily inferred. Figure 8 shows the extent to which participants gave similar responses about the different features of Sikameinan, following the formula described in section 3.1. We found that participants agreed most on why Sikameinan attacks people (not sharing), followed by the number of Sikameinan (one) and the objects used to appease it in ritual (fabric, fishing nets, and necklaces), all of which are represented in the ritual. By contrast, elements of Sikameinan that are not present in the ritual (how it attacks people and the kinds of misfortune it causes) showed much less agreement, both within regions (Fig. 7A) and across them (Fig. 7B). To appreciate the variation in agreement, contrast Figure 1A, which shows participants' responses about why Sikameinan attacks (reason), to Supplementary Figure S2, which shows participants' responses for what happens when it attacks (misfortune). Although we did not quantify this information, participants also varied considerably in how they imagined Sikameinan's appearance (Supplementary Table S8), another feature not represented in the meinan ritual. 

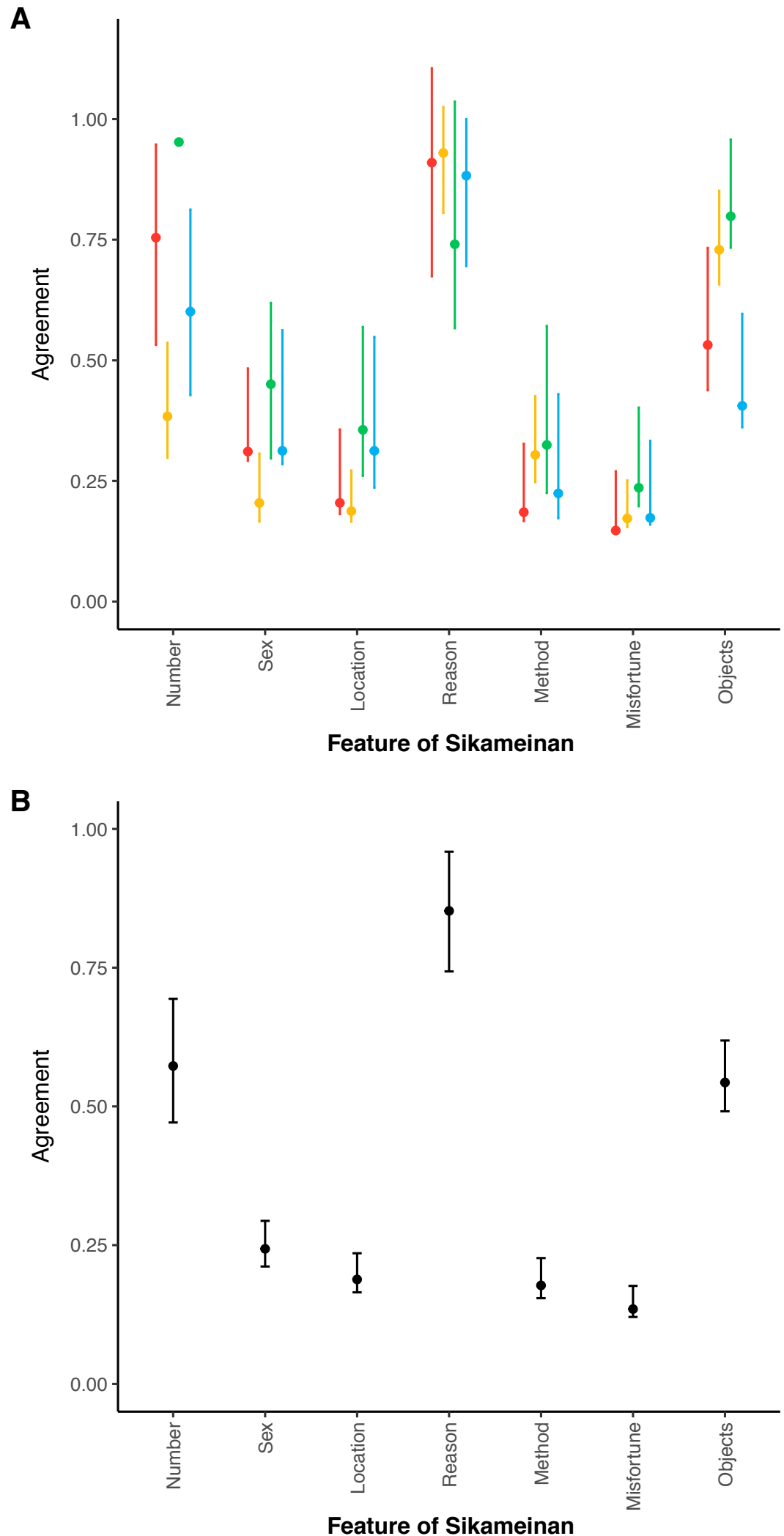
Figure 8. Agreement among participants about different features of Sikameinan (see 3.1 for the full questions). Error bars are bootstrapped 95\% confidence intervals (10,000 samples). Colors correspond with cultural regions: red = Sabirut; yellow = Sareireket; green = Silaoinan; blue = Taileleu. Panel A shows agreement among respondents living in the same cultural region; Panel B shows agreement among respondents pooling across cultural regions.

By this logic, we should expect higher agreement about Sikameinan's sex (female) and location (water). What explains the lower values? For responses about Sikameinan's location, the lower agreement is a result of people's diverse responses. Still, the majority of responses referred to the water (e.g., river, puddles inside broken bamboo), a belief again reinforced in ritual (see Figure 5). For sex, the lower agreement partly reflects the high frequency with which participants responded that they didn't know (Supplementary Figure S4). Moreover, the participants who did respond usually replied that Sikameinan is either female (29\%) or both sexes (23\%) with only 4\% of respondents claiming that Sikameinan is male (Supplementary Table S2). The bias towards Sikameinan being female is what we expect on the basis of Sikameinan's name (aunt) and the objects used to appease it (e.g., the fishing net, which women typically use). This evidence suggests that the Sikameinan ceremony is a potent vehicle for transmitting cultural information and creating shared beliefs among community members.

\section{Discussion}

At the outset of this article, we asked three questions:

1. Are supernatural agents believed to enforce cooperation in small-scale societies and, if so, how does their jurisdiction differ from that of bigger gods in more complex societies?

2. Do beliefs in these supernatural agents motivate people to engage in behavior that would perceived as costly were they not to sincerely hold those beliefs?

3. Does ritual reinforce beliefs in these agents?

For the first question, our study found strong evidence that a supernatural agent in a small-scale society is said to punish non-cooperative behavior. But in comparison with the moralizing forces of world religions, Sikameinan's scope and domain of interest are limited. Whereas moralistic supernatural forces such as karma or the Christian god are believed to care about large-scale morality, including whether one is greedy, harmful, unkind, or dishonest towards socially distant individuals such as strangers (White \& Norenzayan, 2019), Sikameinan attacks people who fail to share meat with fellow clan members. Unlike karma or the Christian god (White \& Norenzayan, 2019), Sikameinan cannot read minds, which is implied in the shamans' assurance to the spirit that the patient's failure to share was inadvertent. Sikameinan is morally concerned but provincial in its scope and limited in its knowledge compared to the powerful gods of the largest-scale societies (see also Tyvan spirit-masters: Purzycki, 2016; Purzycki, 2013).

For the second question, our findings suggest that beliefs in supernatural punishment motivate people to incur costs. Patients and their families pay for shamans to come and remove Sikameinan from their homes, and they do so at the expense of other treatment options, such as visiting a health clinic. Moreover, shamans call other shamans to perform the ceremony, and shamans even perform the ceremony in private. 
An alternative explanation for these observations is that people's representations of Sikameinan do not motivate them to incur costs and instead families host the ceremony for reputational benefits, perhaps because it broadcasts to observers that they fear Sikameinan and can therefore be trusted. Aside from the fact that such a hypothesis still invokes erroneous beliefs - observers would erroneously infer that the family holds Sikameinan beliefs that make them trustworthy - readers should also be aware that conducting a Sikameinan ceremony is an admission that one violated an important social norm. Future research should evaluate the inferences observers make about families that host Sikameinan ceremonies and test whether Sikameinan beliefs have other effects on behavior, such as motivating prosocial decision-making.

For the final question, our study showed that ritual and belief can mutually reinforce each other. People's belief that Sikameinan harmed them or their family motivates them to call shamans to conduct the appropriate ceremony. The costly and public nature of the ceremony in turn strengthens observers' beliefs about Sikameinan, especially the idea that Sikameinan punishes for not sharing. The patient's recovery, such as through the spontaneous remission of the illness or, possibly, placebo effects stimulated by ritual healing (Kaptchuk, 2011), further convinces patients and observers that the ceremony worked and that Sikameinan was the originating cause of the illness. The belief-producing effects of ritual manifest in population-level variation in beliefs. Those beliefs that vary the least across individuals are represented in ritual, while those beliefs not represented vary the most. Belief motivates ritual; ritual reproduces belief (Figure 9; see also Henrich, 2009).

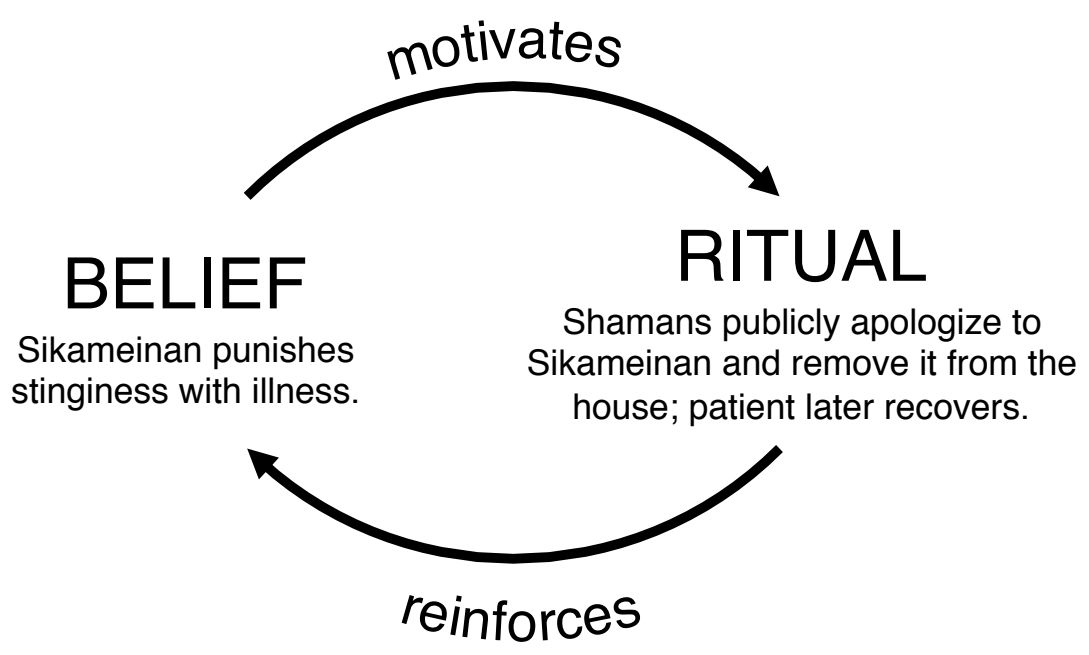

Figure 9. Belief in Sikameinan and rituals (healing ceremonies in which shamans remove it) seem to mutually reinforce each other.

A single ethnographic case study need not necessarily generalize. That Sikameinan is moralistic tells us little about the frequency of supernatural punishers in animist traditions more broadly. Still, our findings are consistent with observations of scholars such as Boehm (2008) and Watts, Greenhill et al. (2015). In their ethnographic surveys of small-scale societies, these researchers found evidence of beliefs in spirits that care about cooperation. Crucially, they noted 
that those spirits seem to be less powerful and to have smaller moral jurisdictions. Our detailed investigation of Sikameinan, combined with ethnographic surveys, substantially qualifies the classical anthropological view that moralistic supernatural forces are restricted to modern, largescale societies.

To what extent did interactions with world religions in the twentieth century shape these beliefs and practices? Three lines of evidence suggest that answer is "not very much". First, the four regions studied have experienced distinct histories of religious contact and acculturation, yet they reported strikingly similar beliefs about Sikameinan. In the region of Sabirut, Protestant missionaries arrived in the 1930s, followed soon by Islam and Catholicism. This region was also dramatically affected by governmental programs bent on eradicating traditional Mentawai culture. The people of Buttui, in contrast, were better able to escape early missionizing and government acculturation. They first encountered Baha'i in the 1950s, followed later by Catholicism and much more recently by Islam. All the while, they actively maintained traditional practices. Salappa seems to have had a similar history to Buttui insofar as Baha'i arrived first followed by Christianity, although Islam may have come there earlier. We know less about the history of Taileleu. It seems unlikely that, despite variation in which world religions these communities encountered and in the intensity of those interactions, the peoples in these communities convergently constructed Sikameinan so that it specifically attacks people who do not share meat.

The second reason why these beliefs seem to predate recent missionizing activity is that they are consistent with those described by Schefold (1988). Starting in 1967, Schefold conducted fieldwork with Sakuddei, a remote Mentawai clan that had evaded outside contact. If missionaries appreciably affected these beliefs, we would expect Sakuddei to have been much less affected in 1967 and for the contemporary people living in Sabirut (Maileppet and Muntei) to be much more affected. For instance, the Sakuddei conception of Sikameinan might have been less moralistic while the modern Sabirut conception might be more so, with a broader moral jurisdiction. Instead, Sakuddei's conception of Sikameinan seems to have been strikingly similar to the one documented throughout southern Siberut: A punitive water spirit associated with crocodiles attacks non-sharers, and shamans are called to remove that spirit in a public ceremony.

The third line of evidence suggesting minimal recent influence consists of the observations of early ethnographers. In 1921, Kruyt, a missionary and ethnographer, spent two months in the archipelago. He reported that people referred to water spirits as "kameinan" and that these water spirits directed crocodiles to attack individuals who broke taboos or who, in anger, threw food, damaged property, or split wood that they did not mean to use (Kruyt, 1923, pp. 103-104). In the same ethnography, he reported that malevolent kameinan had loose hair and wide shirts and were also known in some areas as Sibeulepei ("sibeoelepei"). They became angry either when people disturbed their habitat, such as by washing entrails there, and, crucially, when people did not distribute equal portions of fish (Kruyt, 1923, p. 153). (Confusingly, Kruyt then asserted that kameinan spirits were not associated with crocodiles, contradicting his earlier observation.) Kruyt's observations differ slightly from ours, which may be due to his short time in the archipelago, the diverse locations (he visited North Pagai and southern Siberut), or changes that have occurred since then. But he documented beliefs in a punitive water spirits that were known by the word "aunt" (kameinan), punished non-sharing, could be appeased by shamans, and, depending on the particular passage you cite, were associated with crocodiles (see also 
Loeb's (1929a, 1929b) descriptions of punitive crocodiles from his research in the Pagai Islands in 1926, although he does not mention food-sharing).

If interactions with modern missionizing religions did not have a significant effect on the reported beliefs and rituals, what about earlier contact with outsiders? The Portuguese were aware of the islands as early as 1606, although they seem not to have landed (Tulius, 2012). According to the Englishman John Crisp, who visited the Pagai ("Poggy") islands in August $1792^{3}$, the English had attempted to cultivate pepper there 40 or 50 years earlier (Crisp, 1799). Even before Europeans knew of the Mentawai Islands, the inhabitants likely traded with Malay and Chinese merchants from Sumatra. Crisp reported that the Mentawai he met wore beads and used machetes, and he saw Malays in the Pagai Islands during his visit. Moreover, items like gongs and iron cooking pots are central features of Mentawai social life and likely streamed in from trade with outsiders before European contact. We cannot reject the possibility that these longstanding interactions somehow shaped the beliefs we have reported, even among those groups that never met Europeans or merchants from Sumatra.

Even if these beliefs were shaped by outside pressures, the belief in a punitive spirit connected to crocodiles seems to have deep roots. The people of Nias-who are the Mentawai's closest linguistic relatives and the most similar of 70 Indonesian communities, to the Mentawai in terms of mtDNA (Hammarström, Forkel, \& Haspelmath, 2019; Tumonggor et al., 2013)regarded crocodiles as both gatekeepers to the underworld (Marschall, 2010) and punitive agents (Bakels, 1994). Nias society was much more socially stratified than in Mentawai, however, and the punitive power of crocodiles was closely connected to the chief. There, crocodiles were said to attack condemned prisoners and to devour escapees as they crossed rivers.

In closing, we hope our study demonstrates the capacity for primary ethnographic research to provide rich descriptions of behavior in diverse societies and address targeted research questions. This point is important, because, as with all sciences, the naturalistic study of cultural behavior is undergoing a methodological revolution. Researchers increasingly draw on massive online experiments, cross-cultural studies, and analyses of large-scale databases to test the behavioral and historical predictions of existing theories (Mehr et al., 2019; Purzycki et al., 2016; Slingerland \& Sullivan, 2017; Watts, Sheehan, et al., 2015). These methods open up novel research programs, but they have limitations. Analyses of large-scale databases must leverage existing descriptions, and despite the richness of the ethnographic and historical record, many observers failed to document behaviors and beliefs that are most relevant for key questions. A comprehensive understanding of human behavior requires a diverse methodological toolkit, including rich and detailed ethnographic investigations.

\footnotetext{
${ }^{3}$ Crisp described Mentawai culture, but did not mention Sikameinan. In the passage most relevant to this paper, he wrote, "Sometimes a fowl and sometimes a hog is sacrificed to avert sickness; to appease the wrath of the offender power, or to render it propitious to some projected enterprise... But they have no form of religious worship, nor do they appear to have the most distant idea of a future state of rewards and punishment (Crisp, 1799, p. 86).”
} 


\section{References}

Aksi Peduli Bangsa. (2020). Tentang kami - Sejarah. Retrieved April 10, 2020, from http://aksipedulibangsa.org/tentang-kami/

Bakels, J. (1994). But his stripes remain: On the symbolism of tiger in the oral tradition of Kerinci, Sumatra. In Text and Tales: Studies in Oral Tradition (pp. 33-51).

Bakker, L. (1999). Tiele! Turis! The social and ethnic impact of tourism in Siberut (Mentawai). Leiden University.

Barrett, J. L. (2000). Exploring the natural foundations of religion. Trends in Cognitive Sciences, 4(1), 29-34.

Barro, R. J., \& McCleary, R. M. (2006). Religion and economic growth across countries. American Sociological Review, 68(5), 760. https://doi.org/10.2307/1519761

Barth, F. (1975). Ritual and knowledge among the Baktaman of New Guinea. New Haven: Yale University Press.

Baumard, N., \& Boyer, P. (2013). Explaining moral religions. Trends in Cognitive Sciences, 17(6), 272-280. https://doi.org/10.1016/j.tics.2013.04.003

Boehm, C. (2008). A biocultural evolutionary exploration of supernatural sanctioning. In J. Bulbulia, R. Sosis, E. Harris, R. Genet, C. Genet, \& K. Wyman (Eds.), Evolution of religion: Studies, theories, and critiques. Santa Margarita, CA: Collins Foundation Press.

Boyer, P. (2001). Religion explained: The evolutionary origins of religious thought. New York: Basic Books.

Boyer, P. (2018). Minds make societies: How cognition explains the world humans create. Yale University Press.

Boyer, P. (2019). Informal religious activity outside hegemonic religions: wild traditions and their relevance to evolutionary models. Religion, Brain and Behavior. https://doi.org/10.1080/2153599X.2019.1678518

Chwe, M. S.-Y. (2001). Rational ritual. Princeton: Princeton University Press.

Clingingsmith, D., Khwaja, A. I., \& Kremer, M. (2009). Estimating the impact of the Hajj: Religion and tolerance in Islam's global gathering. Quarterly Journal of Economics, 124(3), 1133-1170.

Crisp, J. (1799). An account of the inhabitants of the Poggy, or Nassau Islands, lying off Sumatra. Asiatick Researches, or, Transactions of the Society Instituted in Bengal, for Inquiring into the History and Antiquities, the Arts, Sciences, and Literature of Asia, 6, 77-92.

Delfi, M. (2013). Islam and Arat Sabulungan in Mentawai. Al-Jami'ab: Journal of Islamic Studies, 51(2). https://doi.org/10.14421/ajis.2013.512.475-499

Edelman, B. (2009). Red light states: Why buys online adult entertainment? Journal of Economic Perspectives, 23(1), 209-220. https://doi.org/10.1257/jep.23.1.209

Gervais, W. M., \& Henrich, J. (2010). The Zeus Problem: Why Representational Content Biases Cannot Explain Faith in Gods. Journal of Cognition and Culture, 10(3), 383-389. https://doi.org/10.1163/156853710X531249

Hammarström, H., Forkel, R., \& Haspelmath, M. (2019). Glottolog 4.1. Retrieved February 6, 2020, from http://glottolog.org

Hammons, C. S. (2010). Sakaliou: Reciprocity, mimesis, and the cultural economy of tradition in Siberut, Mentawai Islands, Indonesia. University of Southern California.

Henrich, J. (2009). The evolution of costly displays, cooperation and religion: credibility 
enhancing displays and their implications for cultural evolution. Evolution and Human Behavior, 30(4), 244-260. https://doi.org/10.1016/j.evolhumbehav.2009.03.005

Hill, K. R., Walker, R. S., Bozicević, M., Eder, J., Headland, T., Hewlett, B., ... Wood, B. (2011). Co-residence patterns in hunter-gatherer societies show unique human social structure. Science (New York, N.Y.), 331(6022), 1286-1289.

https://doi.org/10.1126/science.1199071

Indigenous Education Foundation. (2012). 2011-2012 community research report.

Kapitány, R., Nelson, N., Burdett, E. R., \& Goldstein, T. R. (2019). The child's pantheon: Children's bierarchical belief structure in real and non-real figures.

Kaptchuk, T. J. (2011). Placebo studies and ritual theory: a comparative analysis of Navajo, acupuncture and biomedical healing. Philosophical Transactions of the Royal Society of London. Series B, Biological Sciences, 366(1572), 1849-1858. https://doi.org/10.1098/rstb.2010.0385

Kruyt, A. C. (1923). De Mentawaiers. Indische Taal, Land-En Volkenkunde, 62, 1-188.

Lang, M., Purzycki, B. G., Apicella, C. L., Atkinson, Q. D., Bolyanatz, A., Cohen, E., ... Henrich1, J. (2019). Moralizing gods, impartiality and religious parochialism across 15 societies. Proceedings of the Royal Society B: Biological Sciences, 286(1898), 20190202. https://doi.org/10.1098/rspb.2019.0202

Lanman, J. A., \& Buhrmester, M. D. (2017). Religious actions speak louder than words: exposure to credibility-enhancing displays predicts theism. Religion, Brain and Behavior, 7(1), 3-16. https://doi.org/10.1080/2153599X.2015.1117011

Loeb, E. M. (1929a). Mentawei myths. Bijdragen Tot de Taal-, Land-En Volkenkunde van Nederlandsch-Indie, 85(1), 66-244.

Loeb, E. M. (1929b). Mentawei religious cult. University of California Publications in American Archaeology and Ethnology, 25(2), 185-247.

Loeb, E. M. (1929c). Shaman and seer. American Anthropologist, 31(1), 60-84.

Marschall, W. (2010). Nias and Simeulue. In A. Graf, S. Schröter, \& E. Wieringa (Eds.), Aceh, bistory, politics, and culture (pp. 227-242). Singapore: Institute of Southeast Asian Studies.

Mehr, S. A., Singh, M., Knox, D., Ketter, D. M., Pickens-Jones, D., Atwood, S., ... Glowacki, L. (2019). Universality and diversity in human song. Science, 366, eaax0868. https://doi.org/10.1126/science.aax0868

Norenzayan, A. (2013). Big gods: How religion transformed cooperation and conflict. Princeton University Press.

Norenzayan, A., Shariff, A. F., Gervais, W. M., Willard, A. K., McNamara, R. A., Slingerland, E., \& Henrich, J. (2016). The cultural evolution of prosocial religions. Behavioral and Brain Sciences, 39, e1. https://doi.org/10.1017/S0140525X14001356

Peoples, H. C., Duda, P., \& Marlowe, F. W. (2016). Hunter-gatherers and the origins of religion. Human Nature. https://doi.org/10.1007/s12110-016-9260-0

Peoples, H. C., \& Marlowe, F. W. (2012). Subsistence and the evolution of religion. Human Nature, 23(3), 253-269. https://doi.org/10.1007/s12110-012-9148-6

Pew Research Center. (2017). The changing global religious landscape.

Purzycki, B. G. (2013). The minds of gods: A comparative study of supernatural agency. Cognition, 129(1), 163-179. https://doi.org/10.1016/j.cognition.2013.06.010

Purzycki, B. G. (2016). The evolution of gods' minds in the Tyva Republic. Current Anthropology, 57(June), S000-S000. https://doi.org/10.1086/685729

Purzycki, B. G., Apicella, C., Atkinson, Q. D., Cohen, E., McNamara, R. A., Willard, A. K., 
... Henrich, J. (2016). Moralistic gods, supernatural punishment and the expansion of human sociality. Nature, 1-10. https://doi.org/10.1038/nature16980

Purzycki, B. G., \& Sosis, R. (2019). Resistance, subversion, and the absence of religion in traditional societies.

Purzycki, B. G., Willard, A. K., Kundtov, E., Apicella, C., Atkinson, Q., Bolyanatz, A., ... Ross, C. T. (2020). The Moralization Bias of Gods' Minds: A Cross-Cultural Test.

$\mathrm{R}$ Core Team. (2015). R: A language and environment for statistical computing. Retrieved from http://www.r-project.org/

Reeves, G. (2000). Entities of life; entities of death. In The anthropology of the Mentawai Islands. Retrieved from https://www.mentawai.org/anthropology-92-93/7-entities-of-life-entitiesof-death/

Roes, F., \& Raymond, M. (2003). Belief in moralizing gods. Evolution and Human Bebavior, 24(2), 126-135. https://doi.org/10.1007/s12110-014-9214-3

Rossano, M. J. (2007). Supernaturalizing social life: Religion and the evolution of human cooperation. Human Nature, 18(3), 272-294. https://doi.org/10.1007/s12110-007-9002-4

Rossano, M. J. (2012). The essential role of ritual in the transmission and reinforcement of social norms. Psychological Bulletin, 138(3), 529-549. https://doi.org/10.1037/a0027038

Rudito, B. (2001). Magi sebagai acuan identitas diri orang Mentawai dalam hubungan antar suku bangsa. Makalah Dalam 2nd International Symposium of The Journal Antropologi Indonesia Globalization and Local Culture: A Dialectic towards the New Indonesia, 18-21 July 2001. Padang: Universitas Andalas.

Schefold, R. (1982). The culinary code in the puliaijat ritual of the Mentawaians. Bijdragen Tot de Taal-, Land-En Volkenkunde, 138, 64-97. https://doi.org/10.1163/22134379-90003482

Schefold, R. (1988). Lia: Das grosse Ritual auf den Mentawai-Inseln (Indonesien). Berlin: Dietrich Reimer Verlag.

Schefold, R. (1998). The domestication of culture: Nation-building and ethnic diversity in Indonesia. Bijdragen Tot de Taal-, Land- En Volkenkunde, 154(2), 259-280. https://doi.org/10.1163/22134379-90003898

Schefold, R. (2007). Ambivalent blessings: Head-hunting on Siberut (Mentawai) in a comparative Southeast Asian perspective. Anthropos, 102, 479-494.

Shariff, A. F., \& Rhemtulla, M. (2012). Divergent Effects of Beliefs in Heaven and Hell on National Crime Rates. PLoS ONE, 7(6), e39048. https://doi.org/10.1371/journal.pone.0039048

Shariff, A. F., Willard, A. K., Andersen, T., \& Norenzayan, A. (2015). Religious priming: A meta-analysis with a focus on prosociality. Personality and Social Psychology Review, (November). https://doi.org/10.1177/1088868314568811

Singh, M. (2018). The cultural evolution of shamanism. Behavioral and Brain Sciences, 41, e66. https://doi.org/10.1017/S0140525X17001893

Singh, M., \& Henrich, J. (2020). Why do religious leaders observe costly prohibitions? Examining taboos on Mentawai shamans. Evolutionary Human Sciences, 2, e32. https://doi.org/10.1017/ehs.2020.32

Slingerland, E., \& Sullivan, B. (2017). Durkheim with data: The Database of Religious History. Journal of the American Academy of Religion, 85(2), 312-347.

https://doi.org/10.1093/jaarel/lfw012

Sosis, R. (2006). Religious behaviors, badges, and bans: Signaling theory and the evolution of 
religion. In P. McNamara (Ed.), Where god and science meet: How brain and evolutionary studies alter our understanding of religion (Vol. 1).

Tulius, J. (2012). Family stories: oral tradition, memories of the past, and contemporary conflicts over land in Mentawai - Indonesia. Leiden University.

Tumonggor, M. K., Karafet, T. M., Hallmark, B., Lansing, J. S., Sudoyo, H., Hammer, M. F., \& Cox, M. P. (2013). The Indonesian archipelago: an ancient genetic highway linking Asia and the Pacific. Journal of Human Genetics, 58(3), 165-173. https://doi.org/10.1038/jhg.2012.154

Tylor, E. B. (1920). Primitive culture: Researches into the development of mythology, philosophy, religion, language, art, and custom, vol. 2 (6th Ed.). Retrieved from https://archive.org/details/primitiveculture02tylouoft

Watts, J., Greenhill, S. J., Atkinson, Q. D., Currie, T. E., Bulbulia, J., \& Gray, R. D. (2015). Broad supernatural punishment but not moralizing high gods precede the evolution of political complexity in Austronesia. Proceedings of the Royal Society B, 282, 20142556.

Watts, J., Sheehan, O., Atkinson, Q. D., Bulbulia, J., \& Gray, R. D. (2016). Ritual human sacrifice promoted and sustained the evolution of stratified societies. Nature, 1-7. https://doi.org/10.1038/nature17159

Watts, J., Sheehan, O., Greenhill, S. J., Gomes-Ng, S., Atkinson, Q. D., Bulbulia, J., \& Gray, R. D. (2015). Pulotu: Database of Austronesian supernatural beliefs and practices. PLoS ONE, 1O(9), 1-17. https://doi.org/10.1371/journal.pone.0136783

White, C. J. M., \& Norenzayan, A. (2019). Mental models: Associations between beliefs about karma and God, moral values, and prosocial behavior. PsyArxiv. Retrieved from https://psyarxiv.com/a7398/

Whitehouse, H. (1995). Inside the cult: Religious innovation and transmission in Papua New Guinea. Clarendon Press.

Whitehouse, H. (2002). Modes of religiosity: Towards a cognitive explanation of the sociopolitical dynamics of religion. Method E Theory in the Study of Religion, (14), 293-315.

Whitehouse, H. (2004). Modes of religiosity: A cognitive theory of religious transmission. Walnut Creek, CA: AltaMira Press.

Whitehouse, H., \& Lanman, J. A. (2014). The Ties That Bind Us. Current Antbropology, 55(6), 674-695. https://doi.org/10.1086/678698

Wiener-Bronner, D. (2020, March 13). Online sales of hand sanitizer and other "virus protectors" spiked over 800\% this year in the US. Retrieved April 11, 2020, from CNN Business website: https://www.cnn.com/2020/03/13/business/hand-sanitizersales/index.html

Woolley, J. D., Boerger, E. A., \& Markman, A. B. (2004). A visit from the Candy Witch: Factors influencing young children's belief in a novel fantastical being. Developmental Science, 7(4), 456-468. https://doi.org/10.1111/j.1467-7687.2004.00366.x 